\title{
ANALISIS PERLAKUAN AKUNTANSI TENTANG AKAD RAHN UNTUK PEMBIAYAAN ARRUM BERDASARKAN PSAK NO 107 DAN FATWA DSN MUI NO 26 PADA PEGADAIAN SYARIAH CABANG LANDUNGSARI MALANG Haris Shofiyana
}

\author{
Jurusan Akuntansi Fakultas Ekonomi \\ Universitas Islam Negeri Maulana Malik Ibrahim Malang \\ Email : harisshofiyana@gmail.com
}

\begin{abstract}
The concept which is far from riba (usury) and is corresponding with Islamic Law makes the Islamic Mortgage Institution is demanded by some people, especially the middle-lower class society because of the requirements are easy to be fulfilled, accessible and can be done with a relatively short time. With the easiness to obtain loan capital in the form of funds for customers who own a business or run a business by mortgaging his property in the form of gold or diamonds. One of the Islamic Mortgaging Institution's products that provide loan financing to customers engaged in business is gold Arrum Financing with the installment payment system which is conforming with Sharia principles. The purpose of this research is to know how Accounting Treatment of Rahn's Contract (Akad Rahn) for Arrum Financing Based On PSAK 107 and Decree of DSN MUI at Islamic Mortgage Institution Branch Landungsari Malang. This research is design as qualitative method with using descriptive approach. This research is done by three stages, (1) data collection is done by interview, observation, documentation, and online data searching (2) data analysis technique, (3) data analysis with data reduction procedures, data presentation, and conclusion. The results of this study indicate that the Islamic Mortgage Institution of Landungsari Malang about Rahn's contract for Arrum Financing has implemented accounting guidance of PSAK 107 and has been in accordance with the application of Decree of Dewan Standar Nasional Nasional Majlis Ulama Indonesia No.26 / DSN-MUI / III / 2002.
\end{abstract}

Keywords:Contract of Rahn, Arrum Financing, PSAK 107, Decree of DSN MUI 26

\begin{abstract}
Abstrak
Konsep yang jauh dari riba dan sesuai syariat Islam, membuat Pegadaian Syariah merupakan lembaga keuangan yang diminati oleh sebagian masyarakat, khususnya masyarakat menengah ke bawah karena mudahnya persyaratan yang harus dipenuhi, mudah diakses dan dapat dilakukan dengan waktu yang relatif singkat. Melihat mudahnya memperoleh pinjaman modal dana bagi nasabah yang memiliki usaha atau menjalankan usaha dengan cara menggadaikan barang miliknya berupa emas atau berlian. Salah satu produk Pegadaian Syariah yang memberi pembiayaan pinjaman kepada nasabah yang bergerak dibidang usaha adalah pembiayaan arum emas dengan pengembalian sistem angsuran yang berprinsip Syariah. Tujuan dari penelitian in adalah untuk mengetahui bagaimana Perlakuan Akuntansi Tentang Akad Rahn Untuk Pembiayaan Arum Berdasarkan PSAK 107 dan Fatwa DSN MUI no 26 Pada Pegadaian Syariah Cabang Landungsari Malang". Penelitian ini menggunakan metode kualitatif dengan jenis pendekatan deskriptif. Penelitian ini dilakukan dengan tiga tahapan yaitu, (1) pengumpulan data dilakukan dengan
\end{abstract}


wawancara, observasi, dokumentasi, dan penelusuran data on-line (2) teknik analisis data, (3) analisis data dengan langkah-langkah reduksi data, penyajian data, dan penarikan kesimpulan. Hasil penelitian ini menunjukkan bahwa, Pegadaian Syariah Cabang Landungsari Malang tentang akad rahn untuk pembiayaan arrum telah menjalankan pedoman akuntansi PSAK 107, dan telah sesuai dengan penerapan Fatwa Dewan Standar Nasional Majlis Ulama Indonesia No.26/DSN-MUI/III/2002.

Kata Kunci: Akad Rahn, Pembiayaan Arrum, PSAK 107, Fatwa DSN MUI No 26 


\section{PENDAHULUAN}

Pegadaian Syariah merupakan lembaga keuangan yang diminati oleh sebagian masyarakat, khususnya masyarakat menengah ke bawah karena mudahnya persyaratan yangharus dipenuhi, mudah diakses dan dapat dilakukan dengan waktu yang relatif singkat. Dalammemperoleh pinjaman modal dana pada pegadaian maka pihak nasabah hanya perlumembawa barang jaminan yang akan digadaikan, identitas diri dan mengisi form pengajuangadai yang telah disediakan oleh pihak pegadaian. Setelah itu barang jaminan akan ditaksiroleh pihak pegadaian untuk mengetahui berapa pinjaman maksimal yang di peroleh nasabah.(Pegadaian Syariah,2017)

Menurut Adrian Sutedi menjelaskan bahwa akad dalam pegadaian Syariah secara umum,menggunakan dua akad yakni akad Rahn dan akad Ijarah. Akan tetapi, kebijakan daripegadaian pusat yang baru menetapkan bahwa setiap transaksi menggunakan satu akad yakniakad Rahn. Melalui akad tersebut, pihak pertama (nasabah) menyerahkan harta atau barangbergerak, kemudian pihak kedua (pegadaian syariah) menyimpan dan merawat barang miliknasabah. Akibat yang timbul dari proses pembiayaaan adalah biaya perawatan dankeseluruhan proses kegiatannya. Biaya yang dimaksud di atas yaitu untuk biaya perawatan,pemeliharaan serta sewa tempat di Pegadaian bisa disebut biaya mu'nah atau ujroh.

Pegadaian Syariah Cabang Landungsari Malang terus berkomitmen mengembangkanproduk-produk jasa keuangan yang dibutuhkan masyarakat. Salah satunya menawarkanproduk pembiayaan Arrum, di mana produk tersebut sangat menarik perhatian nasabahnya

yang bergerak di bidang usaha. Arrum merupakan kepanjangan dari Ar-Rahn untuk usaha mikro dan kecil. Pembiayaan Arrum Emas merupakan Produk yang ditujukan kepada nasabah yang menjalankan usaha melalui pinjaman atau pembiayaan bagi keperluan produktif dengan sistem pengembalian secara angsuran yang berprinsip Syariah dengan menggunakan jaminan Emas atau Berlian dan logam emas, serta yang sesuai dengan Fatwa DSN MUI No.26/DSN-MUI/III/2008. (Pegadaian Syariah, 2017)

Dasar pelaksanaan Pembiayaan Arum Emas ini telah diatur oleh Dewan Syariah Nasionaldalam fatwa Dewan Syariah Nasional Majlis Ulama Indonesia Nomor 26/DSN- 
MUI/III/2008tentang Rahn Emas yang menyatakan bahwa Rahn Emas diperbolehkan berdasarkan PrinsipRahn no.25/DSN-MUI/III/2008 dengan PSAK No 107 merupakan panduan dalampengakuan, pengukuran, penyajian, dan pengungkapan yang berhubungan denganPembiayaan Arum Emas.Berdasarkan uraian yang telah dikemukakan di atas, peneliti tertarik untuk mengetahuilebih lanjut bagaimana perlakuan akuntansi Pembiayaan Arrum Emas sehingga menjadi latarbelakang peneliti untuk melakukan penelitian yang mengangkat judul "Analisis PerlakuanAkuntansi tentang Akad Rahn untuk Pembiayaan Arrum Berdasarkan PSAK No 107dan Fatwa DSN MUI No 26 pada Pegadaian Syariah Cabang Landungsari Malang”.

\title{
TINJAUAN PUSTAKA
}

\begin{abstract}
Akad Rahn
Menurut Syafe'I (2000:159) Secara etimologis, arti Ar-Rahn adalah tetap, kekal dan jaminan, sedangkan al-habsu berarti penahanan terhadap suatu barang dengan hak sehingga dapat dijadikan sebagai pembayaran dari barang tersebut.Sedangkan menurut Sabiq dalam bukunya Anshor (2005:139). Menjelaskan bahwaRahn adalah menjadikan barang yang mempunyai nilai harta. Menurut pandangan syara'sebagai jaminan hutang, hingga orang yang bersangkutan boleh mengambil hutang atau iabisa mengambil sebagian (manfaat) barangnya itu. Pengertian ini didasarkan pada praktikbahwa apabila seseorang ingin berhutang kepada orang lain, maka ia menjadikan barangmiliknya baik berupa barang tak bergerak atau berupa barang bergerak berada di bawahpenguasaan pemberi pinjaman sampai penerima pinjaman melunasi hutangnya.Dari beberapa pengertian di atas dapat di simpulkan bahwa pengertian rahn adalahmenahan harta salah satu milik si peminjam sebagai jaminan atas pinjaman yang diterimanyaSecara sederhana dapat dijelaskan bahwa rahn adalah semacam jaminan utang atau gadai.Pengertian gadai yang ada dalam syariah agak berbeda dengan pengertian gadai yang adadalam hukum positif, sebab pengertian gadai dalam hukum positif seperti yang tercantumdalam Burgerlihk Wetbook Kitab Undang-Undang Hukum Perdata pasal 1150 adalah
\end{abstract}

"suatu hak yang diperoleh seseorang berpiutang atas suatu barang bergerak, yang diserahkan kepadanya oleh seseorang yang berhutang atau oleh orang lain atas namanya dan memberikan kekuasaan kepada si berhutang itu untuk mengambil pelunasan dari barang tersebut secara didahulukan dari pada orang-orang yang berpiutang lainnya, dengan pengecualian biaya untuk mengambil pelunasan dari barangtersebut dan biaya-biaya mana harus didahulukan”. (UUHP Pasal 1150)

\section{B. Fatwa Dewan Standar Nasional}


1. Dewan Syariah Nasional (DSN) merupakan sebuah lembaga yang berada di naungan Majelis Ulama Indonesia (MUI), yang dipimpin oleh Ketua Umum MUI. Fungsi utama Dewan Syariah Nasional (DSN) adalah mengawasi produk-produk lembaga keuangan syariah agar sesuai dengan syariat Islam.Adapun Rahn Emas Syariah, menurut Fatwa DSN No.26/DSN-MUI/III/2002 harusmemenuhi ketentuan umum sebagai berikut:Rahn Emas dibolehkan berdasarkan prinsip Rahn (lihat fatwa DSNNo.25/DSN-MUI/III/2002 tentang akad Rahn).

2. Rahn Emas boleh digunakan berdasarkan prinsip Ar-Rahn,

3. Ongkos dan biaya penyimpanan barang (murtahin) ditanggung oleh penggadai (Rahin).

4. Biaya penyimpanan barang (marhun)

\section{Pembiayaan Arrum Emas}

Pembiayaan Arrum Emas merupakan jaminan pinjaman dengan sistem syariah bagi para pengusaha mikro dan kecil untuk keperluan pengembangan usaha dengan sistem pengembalian secara angsuran, menggunakan jaminan berupa Emas/Berlian (lantakan danatau perhiasan beserta aksesorisnya) sesuai Fatwa DSN MUI No.26/DSNMUI/III/2008.Pembiayaan diberikan dalam jangka waktu tertentu dengan pengembalian pinjamandilakukan dengan cara angsuran dengan menggunakan secara gadai maupun fidusia, skimpinjaman ini diberikan kepada individual pengusaha mikro. Pembiayaan Arrum padapegadaian syariah memudahkan para pengusaha kecil untuk mendapatkan modal usahadengan jaminan emas/berlian.

\section{PSAK No. 107}

Dalam penentuan biaya dan pendapatan sewa di gadai syariah biasanya pihak pegadaian melakukan berdasarkan PSAK 107 yang terkait. Adapun ketentuan atas pencatatan pengakuan dan pengukuran serta penyajian dan pengungkapan pihak Pegadaian Syariah melakukan berdasarkan PSAK 107 adalah sebagai berikut:

\section{Pengakuan dan Pengukuran}

Terdapat beberapa ketentuan untuk pengakuan dan pengukuran yang dijelaskan dalam PSAK 107, yaitu:

1. Pinjaman/ kas dinilai sebesar jumlah yang dipinjamkan pada saat terjadinya. 
2. Pendapatan sewa selama masa akad diakui pada saat manfaat atas asset (sewa tempat)telah diserahkan kepada penyewa (Rahin).

3. Pengakuan biaya penyimpanan diakui pada saat terjadinya.

\section{Penyajian dan Pengungkapan}

Berdasarkan penjelasan yang terdapat dalam PSAK 107, penyajian dan pengungkapan meliputi:

1. Penyajian, pendapatan ijarah disajikan secara neto setelah dikurangi bebanbeban yang terkait. Misalkan beban pemeliharaan dan perbaikan, dan sebagainya.

2. Pengungkapan, murtahin mengungkapkan pada laporan terkait transaksi ijarah danijarah muntahiyyah bin tamlik.

a) Penjelasan umum isi akad yang signifikan yang meliputi tetapi tidak terbatas pada:

i. keberadaan wa'ad pengalihan kepemilikan dan mekanisme yang digunakan(jika ada wa'ad pengalihan kepemilikan);

ii. pembatasan-pembatasan, misalnya ijarah-lanjutan;

iii. agunan yang digunakan (jika ada);

b) Nilai perolehan dan akumulasi penyusutan untuk setiap kelompok aset ijarah; dan

c) Keberadaan transaksi jual dan ijarah (jika ada).

\section{METODOLOGI PENELITIAN}

Dalam penelitian ini, peneliti menggunakan jenis penelitian kualitatif. Sedangkanpendekatan penelitian yang digunakan adalah jenis pendekatan deskriptif. Penelitiankualitatif deskriptif yang digunakan dalam penlitian ini dimaksudkan untukmendeskripsikan dan menggambarkan mengenai Analisis Perlakuan Akuntansi Tentang Akad Rahn untuk Pembiayaan Arrum Emas berdasarkan PSAK No 107 dan Fatwa DSN MUI No 26 pada Pegadaian Syariah Cabang Landungsari Malang.

Penelitian ini dilakukan di Pegadaian Syariah Cabang Landungsari Malang, yang beralamatkan di Jalan Raya Tlogomas Ruko Landungsari Kav 7, Malang - Jawa Timur. 
Pemilihan lokasi tersebut sebagai objek penelitian berdasarkan pertimbangan bahwa Pegadaian Syariah Cabang Malang yang memiliki produk Pembiayaan Arrum Emas dengan menggunakan akad Rahn dan mu'nah sebagai perawatan barang jaminan. Selain itu Pegadaian Syariah Cabang Landungsari merupakan cabang dari Kantor Wilayah Surabaya.Subjek penelitian dalam penelitian kualitatif adalah pihak- pihak yang menjadi sasaran penelitian atau sumber yang dapat memberikan informasi yang dipilih secara purposive bertalian berkaitan dengan tujuan tertentu. Dalam penelitian ini yang menjadi key person adalah Pimpinan Pegadaian Syariah Cabang.

Data yang diperoleh oleh peneliti dengan cara wawancara dengan Bapak Abdus Salam (Pimpinan Cabang), Bapak Zainul Arifin (Kasir), Ibu Arini P (Penaksir) dan Bapak Supandi (bertanggungjaaawab barang jaminan) pada Pegadaian Syariah Cabang Landungsari, Malang. Data primer diperoleh dengan mengajukan beberapa pertanyaan yang berhubungan dengan penelitian yang akan diteliti, seperti bagaimana Pembiayaan Arrum Emas di Pegadaian Syariah Cabang Landungsari, Jenis apa saja yang sering digadaikan untuk jaminan Pembiayaan Arrum Emas, serta bagaimana jika ada nasabah yang melalui jatuh tempo dan bagaimana mekanisme Denda Pembiayaan Arrum Emas pada Pegadaian Syariah Cabang Landungsari Malang.Sugiyono (2016: 224) menjelaskan bahwa teknik pengumpulan dan merupakanlangkah yang paling strategis dalam penelitian, karena tujuan dari penelitian adalahuntuk mendapatkan data. Untuk mendapatkan data-data yang dibutuhkan oleh peneliti,maka langkah-langkah yang ditempuh adalah metode wawancara, metode observasi,metode dokumentasi, metode penelusuran data online.Pada penelitian ini peneliti menggunakan metode analisis data kualitatif deskriptif.Dalam

penelitian ini peneliti menggambarkan dan menjelaskan tentang hal-hal yangberkaitan dengan akad Rahn untuk pembiayaan Arrum Emas berdasarkan PSAK No 107dan Fatwa DSN MUI No 26. Data yang diperoleh peneliti dari wawancara, observasi,dokumentasi, dan penelusuran data online yang akan dijelaskan dan dideskriptifkansecara menyeluruh. Langkah-langkah analisis data adalah pengumpulan data, reduksidata, Penyajian data, penarikan kesimpulan.

\section{PEMBAHASAN}

Salah satu cabang dari Lembaga Pegadaian Syariah yaitu Pegadaian Syariah Cabang Landungsari Malang. Pegadaian Syariah ini didirikan untuk memenuhi kebutuhan masyarakat, khususnya masyarakat muslim yang ingin melakukan transaksi keuangan 
dengan cara menjaminkan barang berharga miliknya untuk mempeoleh sejumlah pinjamanuang yang sesuai dengan prinsip Syariah. Pegadaian Syariah Cabang Landungsari didirikan pada tanggal 5 April 2006. Pada awal pendiriannya Pegadaian Syariah Cabang Landungsari bertempat di jalan raya Tlogomas Malang, kemudian seiring berjalannya waktu pada tanggal 5 April 2011 Pegadaian Syariah Cabang Landungsari berpindah tempat di jalan Ruko Landungsari Indah Kav 7 (sebelah barat pintu masuk terminal Landungsari) Malang hingga saat ini. Pada saat ini Pegadaian Syariah Cabang Landungsari memiliki 3 unit pembantu yang tersebar di wilayah Malang, yaitu Pegadaian Syariah Kauman, Pegadaian Syariah Bunulrejo dan Pegadaian Syariah Pasar Gadang. (30 November 2017)

\section{Produk-Produk Pegadaian Syariah Cabang Landungsari}

Pada umumnya masyarakat mengenal Pegadaian hanya sebagai tempat menggadaikan barang berharga miliknya untuk memperoleh pinjaman kredit saja, padahal disamping itu Pegadaian juga mempunyai produk pembiayaan lainnya yang juga dapat bermanfaat bagi masyarakat. Adapun produk-produk yang ditawarkan oleh Pegadaian Syariah Cabang Landungsari adalah sebagai berikut: 1) Rahn (Gadai Syariah), 2) Arrum BPKB, 3) Arrum Haji, 4) Arrum Emas, 5) Amanah, 6) Mulia, 7) Tabungan Emas, dan 8) Multi Pembayaran Online (MPO).

\section{Pembiayaan Arrum Emas}

Pembiayaan Arrum dalam Pegadaian Syariah Cabang Landungsari Malang atau bisa disebut juga Arrum Emas merupakan penyerahan jaminan atas pinjaman dengan sistem syariah bagi para pengusaha mikro dan kecil untuk keperluan pengembangan usaha dengan sistem pengembalian secara angsuran, menggunakan jaminan berupa Emas/Berlian, (lantakan atau perhiasan emas beserta aksesorisnya) kepada pegadaian sebagai jaminan atas pembiayaan yang diterima nasabah.Pada saat ini produk Arrum Emas di Pegadaian Syariah sangat banyak diminati olehmasyarakat muslim atau non-muslim dari kalangan bawah sampai kalangan atas.Dikarenakan proses tersebut dalam Pembiayaan Arrum Emas sangat mudah dan cepattanpa survey dan tidak berbelit-belit serta tidak memerlukan banyak persyaratan sepertihalnya lembaga keuangan Syariah lainnya. Sesuai dengan Slogan atau Motto pegadaianyaitu "Mengatasi Masalah Tanpa Masalah", maka lembaga Pegadaian Syariah dapatmemberi manfaat bagi msayarakat sebagaimana tempat untuk memperoleh pinjaman uangsecara mudah dan cepat dalam jangka waktu pendek mendesak seperti modal 
untukpengembangan atau membuka usaha dan lain-lain.Pihak Pegadaian Syariah menyatakan bahwa dalam produk Arrum Emas ini tidakmengambil manfaat dari marhun yang dijaminkan nasabah sehingga dapat dikatakanbahwa Pegadaian memberikan "pinjaman dengan jaminan" emas kepada nasabah. Adapunemas yang digadaikan adalah emas dengan kadar 16-24 karat dengan maksimum pinjaman95\% dari nilai taksiran serta biaya perawatan, penyimpana dan sewa tempat atau biayamu'nah.

\section{Perlakuan Akuntansi Gadai Syariah (Pembiayaan Arrum Emas) dengan PSAK107}

Dalam Arrum emas penentuan biaya dan pendapatan sewa (mu'nah atau ujroh) masih dilakukan berdasarkan akad pendamping dari gadai syariah yaitu akad Ijarah (PSAK 107) yang meliputi:
a) Pengakuan dan pengukuran Piutang pembiayaan Arrum Emas,
b) Pengakuan pendapatan dan beban pembiayaan Arrum Emas, dan
c) Penyajian dan pengungkapan pada Laporan Keuangan

\section{Pengakuan dan Pengukuran piutang dalam produk Arrum Emas}

1. Pada saat terjadinya akad pembiayaan Arrum EmasPegadaian Syariah Cabang Landungsari mengakui piutang pada saat akad terjadi danpihak Pegadaian Syariah menyerahkan dana pinjaman pembiayaan tersebut kepadanasabah yaitu pada saat dua belah pihak (Pegadaian Syariah dan nasabah) menandatanganiakad pinjaman tersebut dan mencairkan dana sebesar pokok pinjaman sesuai kesepakatanpihak pegadaian serta nasabah.

2. Pada Saat Penerimaan Angsuran Atau CicilanApabila terdapat penerimaan angsuran atau pembayaran maka pihak PegadaianSyariah mengakuinya sebagai pengurang pokok pembiayaan dan mengakui pendapatansewa (mu'nah) atas biaya mu'nah yang telah diberikan oleh pihak Pegadaian Syariah dankemudian sisanya akan diakui sebagai pengurang pokok pinjaman nasabah.

3. Pada Saat Pegadaian Syariah Menerima Denda Dari Nasabah Pembiayaan Arrum Emas

Pegadaian Syariah Cabang Landungsari Malang mengakui dana kebajikan, jika nasabah pada waktu angsuran yang ditetapkan sering kali menunggak, tentu saja hal tersebut akan dikenai denda oleh pihak Pegadaian Syariah. Di mana Pegadaian Syariah 
mengakui piutang tak tertagih, jika nasabah tidak membayar angsuran yang telah di tentukan oleh pegadaian Syariah dan nasabah.

4. Pada saat Pegadaian syariah Menerima Pelunasan dari NasabahPada saat pelunasan pembiayaan arum emas, Melakukan penyelesaian atauberakhirnya akad pembiayaan arum emas diakui pada saat pokok pembiayaan telahdilunasi oleh nasabah. Karena pembiayaan arum emas ini hanya sebatas sewa tempat saja,maka pihak Pegadaian Syariah lebih memprioritaskan pengakuan biaya sewa(mu'nah/ujroh) kemudian mengembalikan pinjaman pokok dari nasabahnya.

\section{Pengakuan dan Pengukuran Pendapatan Sewa}

Pegadaian Syariah Cabang Landungsari Malang mengakui beban sewa/mu'nah sebagai

pendapatan sewa /mu'nah yaitu pada yaitu pada saat pihak Pegadaian Syariah menerima pembayaran angsuran setiap bulannya. Besarnya pendapatan sewa adalah dari nilai taksiran barang yaitu presentase biaya mu'nah dikali harga taksiran dikali jangka waktu.

\section{Pengakuan dan Pengukuran Pendapatan Sewa}

Pegadaian Syariah Cabang Landungsari Malang mengakui beban administrasi sebagai pendapatan administrasi pada saat surat akad pinjaman sudah ditandatangani oleh kedua belah pihak yaitu pihak pertama (Pegadaian Syariah Cabang Landungsari) dan pihak kedua (Nasabah) serta pokok pinjaman atau dana pembiayaan sudah dicairkan oleh pihak Pegadaian Syariah Cabang Landungsari Malang.

\section{Penyajian Dan Pengungkapan}

Berdasarkan hasil pemaparan data diatas dalam menyajikan dan pengungkapan laporan

keuangan oleh Pegadaian Syariah Cabang Landungsari Malang tidak terdapat catatan akuntansi secara khusus karena dilakukan secara otomatis dan terpusat, adapun penyajian dan pengungkapan sebagai berikut:

1. Piutang pada Pegadaian Syariah Cabang Landungsari Malang disajikan dalam LaporanKeuangan Posisi Keuangan Konsolidasi dan Entitas Anak sebagai Aset Lancar yaknidengan akun pinjaman yang diberikan (setelah dikurangi penyisihan kerugianpenurunan nilai per periode terkait), dan diungkap dalam catatan atas 
laporan keuangankonsolidasi Pegadaian Syariah yakni mengacu pada nilai barang jaminan yangdigunakan oleh nasabah yang terdiri dari pinjaman, usaha gadai dan lain sebagainya.

2. Pendapatan sewa modal dan pendapatan administrasi pada Pegadaian Syariah CabangLandungsari Malang disajikan dalam Laporan Laba Rugi Komprehensif konsolidasisebagai pendapatan usaha. Dalam catatan atas laporan keuangan diungkap bahwa untukusaha gadai, jasa simpanan Syariah dan pinjaman fidusia diakui dengan menggunakanmetode akrual basis (basic acrual).

\section{Kesesuaian Pembiayaan Arrum Emas dengan Fatwa Dewan Syariah Nasional}

Dari penerapan fatwa MUI tersebut oleh Pegadaian Syariah Cabang LangdungsariMalang dalam proses pembiayaan Arrum Emas adalah sebagai berikut:

1. Barang Jaminan. Dalam pelaksanaan pembiayaan arum emas pada Pegadaian SyariahCabang Landungsari Malang, nasabah menyerahkan emas atau berlian kepadapegadaian syariah sebagai jaminan pinjaman dana modal yang diterima oleh nasabah.Sedangkan Pegadaian syariah akan menahan barang yang digadaikan sampai semuahutangnya terlunasi sebagai jaminan. Hal tersebut telah sesuai dengan fatwa DSNMUI nomor 26/DSN-MUI/III/2002 bagian pertama yang menyatakan bahwa rahinemas dibolehkan sesuai berdasarkan prinsin Rahn.

2. Biaya Administrasi. Menurut beberapa ulama' sepakat bahwa biaya yang bersumberdari barang yang digadaikan (Marhun) merupakan tanggung jawab Rahin(penggadai). Oleh karena itu, biaya administrasi akad Rahn dibebankan kepada Rahin.Sebagaimana dalam Fatwa Dewan Standar Nasional No.26/DSNMUI/III/2002 yangpertama menyatakan Rahn Emas dibolehkan berdasarkan prinsip Rahn (lihat FatwaDSN No.25/DSN-MUI/III/2002), dimana Fatwa DSN No. 25/DSN-MUI/III/2002yang nomor 3 menyatakan pemeliharaan dan penyimpanan marhun pada dasarnyamenjadi kewajiban Rahin. Akan tetapi, dapat juga dilakukan oleh Murtahin (penerimagadai).

3. Biaya Pemeliharaan. Sesuai dengan pendapat para jumhur ulama' biaya pemeliharaanatau biaya penyimpanan menjadi tanggung jawab Rahin (penggadai). Karena padadasarnya Rahin (penggadai) masih menjadi pemilik dari 
barang gadai (Marhun)tersebut sehingga Rahin bertanggungjawab atas seluruh biaya yang dikeluarkan olehPihak Pegadaian Syariah dari barang gadai miliknya. Sesuai dengan Fatwa DewanStandar Nasional No.26/DSN-MUI/III/2002 yang nomor empat menyatakan bahwabiaya penyimpanan barang (Marhun) dilakukan berdasarkan akad ijarah (sewa).

\section{SIMPULAN DAN SARAN}

Berdasarkan pembahasan maka dapat disimpulkan bahwa:

1. Perlakuan akuntansi tentang akad Rahn untuk pembiayaan arum pada Pegadaian Syariahcabang Landungsari Malang sudah sesuai PSAK 107 dengan uraian sebagai berikut:

a. Pengakuan dan pengukuran akad rahn untuk pembiayaan arum emas, kejadiankejadian yang penting pada pembiayaan yaitu:

i. Pihak Pegadaian Syariah mengakui piutang pada saat akad terjadi danmenyerahkan dana pinjaman pembiayaan kepada.

ii. Pada saat penerimaan angsuran atau cicilan, apabila terdapat penerimaanangsuran atau pembayaran maka pihak Pegadaian Syariah mengakuinya sebagaipengurang pokok pembiayaan dan mengakui pendapatan sewa (mu'nah/ujroh)atas biaya mu'nah/ujroh yang telah dibayarkan oleh nasabah yang telah menggunakan jasanya.

iii. Pada saat menerima denda, pihak Pegadaian Syariah mengakui dana kebajikan,jika nasabah pada waktu angsuran yang telah ditetapkan sering kali menunggak,tentu saja hal tersebut akan dikenai denda oleh pihak Pegadaian Syariah.

iv. Pada saat pelunasan pembiayaan arum emas, mengenai penyelesaian atauberakhirnya akad pembiayaan arum emas diakui pada saat pokok pembiayaantelah dilunasi oleh nasabah.

b. Pengakuan pendapatan dan beban pembiayaan arum emas

i. Pendapatan mu'nah/ujroh, Pihak Pegadaian Syariah mengakui pendapatanmu'nah/ujroh pada saat pendapatan itu diterima yaitu ketika nasabah membayarangsuran setiap bulannya.

ii. Pendapatan administrasi, pihak Pegadaian Syariah mengakui pendapatanadministrasi pada saat surat akad pinjaman sudah 
ditandatangani oleh kedua belahpihak serta pokok pinjmanan atau dana pembiayaan sudah dicairkan oleh pihakPegadaian Syariah.

iii. Beban dalam kegiatan pembiayaan yang terdiri dari biaya-biaya yang dikeluarkanpihak Pegadaian Syariah menyangkut pembiayaan arum emas yang ditanggungoleh nasabah dan diakui pendapatan oleh pihak Pegadaian Syariah.

c. Penyajian dan pengungkapanBerdasarkan hasil pemaparan data diatas dalam penyajikan dan pengungkapanLaporan Keuangan oleh Pegadaian Syariah Cabang Landungsari Malang tidakterdapat catatan akuntansi secara khusus karena dilakukan secara otomatis danterpusat dalam Laporan Keuangan Konsolidasi PT. Pegadaian (Persero).

2. Pembiayaan Arrum pada Pegadaian Syariah telah sesuai dengan Fatwa Dewan SyariahNasional Majelis Ulama Indonesia No.26/DSS-MUI/III/2002.

\section{Saran}

Berdasarkan hasil pembahasan dan kesimpulan yang telah diuraikan di atas, maka peneliti mengajukan saran sebagai berikut:

Perlu dibuatkan peraturan khusus mengenai akad Rahn untuk pembiayaan arum emas, karena peraturan tersebut belum ada pada PSAK atau peraturan lainnya.Fokus penelitian hanya sebatas pada akad Rahn untuk pembiayaan arum emas. Kepada peneliti selanjutnya, disarankan untuk mengkaji produk 


\section{DAFTAR PUSTAKA}

Anshor, Abdul Ghofur. 2005. Gadai Syariah Di Indonesia Konsep, Implementasi Dan Institusionalisasi. Yogyakarta: Gajah Mada University PressFatwa Dewan Standar Nasional No 26Kitab Undang-Undang Hukum PerdataPSAK 107 Ijarah

Sugiyono. (2016). Metode Penelitian Kombinasi. Bandung: CV Alfabeta

Sugiyono. (2016). Metode Penelitian Kualitatif, Kuantitatif, dan $R$ dan D. Bandung: CVAlfabeta.

Sutedi, Adrian. 2011. Hokum Gadai Syariah. Bandung: Alfabeta.Syafe'I, Rachmat. 2000. Fiqh Muamalah. Bandung: Pustaka Setia. 